\begin{tabular}{|c|c|c|}
\hline & Int.J.Curr.Microbiol.App.Sci (2021) 10(10): $307-313$ & \\
\hline & $\begin{array}{l}\text { International Journal of Current Microbiology and Applied Sciences } \\
\text { ISSN: 2319-7706 Volume } 10 \text { Number } \mathbf{1 0}(\mathbf{2 0 2 1 )} \\
\text { Journal homepage: } \underline{\text { http://www.ijcmas.com }}\end{array}$ & 39 \\
\hline $\begin{array}{l}\text { EXCELLENT } \\
\text { PUBLISHERS }\end{array}$ & & \\
\hline
\end{tabular}

\title{
Oyster Mushroom Cultivation with Reference to Climate
}

\author{
K. Chitra ${ }^{1}$, K. Dhanalakshmi ${ }^{2}$, N. Indra ${ }^{3}$ and V. Ambethgar ${ }^{1}$ \\ ${ }^{1}$ Tamil Nadu Rice Research Institute, Aduthurai, \\ ${ }^{2}$ KVK, Vamban, Tamil Nadu Agricultural University, Coimbatore, India \\ ${ }^{3}$ ARS, Yethapur, Tamil Nadu Agricultural University, Coimbatore, India \\ *Corresponding author
}

Keywords

Mushrooms, chlorophyll, protein, malnutrition, lignocellulose

Article Info

Accepted: 15 September 2021 Available Online: 20 October 2021

\section{A B S T R A C T}

Cultivation of species oyster mushroom (Pleurotus ostreatus) was initiated on experimental basis in Germany by Flack during the year 1917 on tree stumps and wood logs. Growing technology was perfected in USA. The major states in India producing oyster mushroom are Orissa, Karnataka, Maharashtra, Andhra Pradesh, Madhya Pradesh, West Bengal and most of the North Eastern hill states. Mushroom is rich in Vitamin C and B complex and the protein content ranges from 1.6 to 2.5 per cent. The niacin content is about ten times higher than any other vegetables. The folic acid present in oyster mushroom helps to cure anemia. It is suitable for people with hyper-tension, obesity and diabetes due to its low sodium: potassium ratio, starch, fat and calorific value, alkaline ash and high fiber content make them suitable for consumption for those having hyperacidity and constipation. Oyster mushroom (Pleurotus spp.) is fungal fruiting body. A study was undertaken for identifying the best oyster mushroom variety which is suitable to Tiruchirapalli climate. Three oyster mushroom varieties were taken for the study viz., MDU-1, APK-1, CO-2. The isolation was made from mushroom mycelium. These isolates were cultured under PDA medium. Among the isolates CO-2 and MDU-1 produced good growth of mycelium with a prescribed time limit. The paddy straw and paddy seeds were used for mushroom and spawn production. However, the result showed maximum yield MDU-1(3270 g) when compared to CO - 2 (2780 g) and APK-1 (2280g). Oyster mushroom can be growing at moderate temperature ranging from 20 to $30^{\circ} \mathrm{C}$ and humidity $55-80 \%$ for a period of 6 to 8 months in a year. This MDU - 1 was found to perform well with maximum yield in Tiruchirapalli conditions.

\section{Introduction}

Mushrooms, a group of fungi (macro fungus), which lacks chlorophyll and grows either parasitically or saprophytically. Mushrooms with their flavor, texture, nutritional value and high productivity per unit area have been identified as an excellent food source to alleviate malnutrition in developing countries (Eswaran \& Ramabadran, 2000). Mushrooms contain $20-35 \%$ of protein (dry weight), are low in lipids and contain all the nine essential amino acids (Kalac. 2009). Mushroom has been widely cultivated since the 1700's and 
presently more than 30 unknown species are cultivated as foods. Oyster mushroom (Pleurotus spp.), commonly known as "Dhingri" in India, is a lignocellulose loving fungus growing in nature on living or dead tree trunks/stumps or bark. They are easily recognized in nature due to their peculiar morphology with an eccentric short stem or stipe. The Oyster mushroom has been found to be ideal for people suffering from anaemia, hyperacidity, and constipation. Oyster mushrooms are native to Northeastern United States. Pleurotus species (oyster fungus) is an edible mushroom having excellent flavour and taste (Shah et al., 2004). Oyster fungus are rich source of proteins, minerals \& vitamins (Caglarirmak, 2007). Cultivation of oyster mushroom has increased tremendously throughout the world because of their abilities to grow at a wide range of temperature and utilizing various agro-based residues. Growing oyster mushrooms convert a high percentage of the lignocellulosic substrate to fruiting bodies increasing profitability. It requires a short growth time in comparison to other edible mushrooms.

Mushroom survival and multiplication are related to a number of factors, which may act individually or have interactive effects among them (AMGA, 2004). Temperature is one of the most important physical factors affecting the growth and development of oyster mushroom.

The oyster mushroom confers advantages over other mushrooms for its ability to grow on wide range of temperature from 18 to $30^{\circ} \mathrm{C}$ and fast mycelial growth coupled with rapid colonization of substrates are the other characteristics features of this species (Rajarathnam \& Bano, 1987). Hence, there is vast potential for the cultivation of oyster mushroom. The temperature determines the mycelial growth as well as fruiting bodies production

\section{Materials and Methods}

\section{Preparation of substrate}

Paddy straw is chopped into bits of size 2-3', for easy handling and operation and these substrates was soaked in water for about 8 hours to get wet and achieved $65-70 \%$ of moisture content. All these wet substrates were separated from water and excess water was removed properly and then boiled the contents for 1 hour. After cooling, the substrates were thus ready to be used in mushroom cultivation (Srivastava, H. C., \& Bano, J. 2010).

All instruments, glassware's and culture media were sterilized by autoclaving with 15 PSI at $121^{\circ} \mathrm{C}$ for $1-2$ hours. The culture room of the laboratory was cleaned by gently washing with detergent followed by $70 \%$ ethyl alcohol regularly. We prepared 100 bags (Each 25 bags per crop) for mushroom cultivation at the periodical interval of 10 days for continuous harvesting of mushroom.

\section{Results and Discussion}

The mushroom production activity is low investment indoor activity. Cultivation technology of oyster mushroom is very simple which does not require costly infrastructure facilities. Theoretically each crop takes 45- 55 days and under controlled conditions and hence there can be 8 crops per year. The mushroom from each bag was harvested and weighed periodically.

In each experiment 25 bags were sown. First seeding was done in the month of January and the subsequent bags in the succeeding month. The crop of Oyster mushroom was harvested in four flushes. The maximum yield was recorded in crop 2 of about 25936 gm (25.94 $\mathrm{kg}$ ). The crop 4 had showed reduced yield of about $21145 \mathrm{gm}(21.15 \mathrm{~kg})$. The yield of the 
crop 4 was smaller than the yield from others, this might be due to the month April and May $\left(350 \mathrm{C}\right.$ and $40^{\circ} \mathrm{C}$ ) showed high temperature and low relative humidity resulted in low yield. This showed that the yield of mushroom was significantly influenced by temperature and relative humidity. This leads to malformed mushroom due to high temperature and low relative humidity. The overall yield improvement in first and second harvest as explained due to optimum temperature and relative humidity for the development of mycelium, which helped in improving the yield of mushroom.

Table.1 Yield of oyster mushroom (Crop 1) January 22, 2018 - March 15, 2018

\begin{tabular}{|c|c|c|c|c|c|}
\hline Bag & 1 Harvest & 2 Harvest & 3 Harvest & 4 Harvest & Total yield per bag (gm) \\
\hline $\mathbf{1}$ & 270 & 360 & 240 & 140 & 1010 \\
\hline $\mathbf{2}$ & 260 & 520 & 300 & - & 1080 \\
\hline $\mathbf{3}$ & 375 & 420 & 225 & 160 & 1180 \\
\hline $\mathbf{4}$ & 360 & 445 & 310 & 150 & 935 \\
\hline $\mathbf{5}$ & 325 & 410 & - & 200 & 770 \\
\hline $\mathbf{6}$ & 235 & 390 & 145 & - & 1050 \\
\hline $\mathbf{7}$ & 310 & 295 & 280 & 165 & 1135 \\
\hline $\mathbf{8}$ & 340 & 490 & 235 & 70 & 905 \\
\hline $\mathbf{9}$ & 300 & 310 & 215 & 80 & 890 \\
\hline $\mathbf{1 0}$ & 290 & 510 & 90 & - & 890 \\
\hline $\mathbf{1 1}$ & 225 & 485 & 180 & - & 1175 \\
\hline $\mathbf{1 2}$ & 310 & 460 & 225 & 180 & 925 \\
\hline $\mathbf{1 3}$ & 175 & 435 & 315 & - & 1065 \\
\hline $\mathbf{1 4}$ & 340 & 390 & 235 & - & 1265 \\
\hline $\mathbf{1 5}$ & 340 & 490 & 235 & - & 1040 \\
\hline $\mathbf{1 6}$ & 360 & 445 & 310 & 150 & 825 \\
\hline $\mathbf{1 7}$ & 290 & 510 & 125 & 115 & 1080 \\
\hline $\mathbf{1 8}$ & 190 & 395 & 240 & - & 1180 \\
\hline $\mathbf{1 9}$ & 325 & 540 & 215 & - & 1160 \\
\hline $\mathbf{2 0}$ & 260 & 520 & 300 & 100 & 890 \\
\hline $\mathbf{2 1}$ & 370 & 550 & 240 & - & 1185 \\
\hline $\mathbf{2 2}$ & 290 & 510 & 90 & - & 25.85 \\
\hline $\mathbf{2 3}$ & 100 & 435 & 225 & 90 & 210 \\
\hline $\mathbf{2 4}$ & 225 & 400 & 350 & 200 & \\
\hline $\mathbf{2 5}$ & 325 & 410 & 200 & & \\
\hline & & Total yield $(\mathbf{K g})$ & & & \\
\hline & & & & & \\
\hline
\end{tabular}


Table.2 Yield of oyster mushroom (Crop 2) February 10, 2018 - March 30, 2018

\begin{tabular}{|c|c|c|c|c|c|}
\hline Bag & 1 Harvest & 2 Harvest & 3 Harvest & 4 Harvest & Average yield per bag (gm) \\
\hline $\mathbf{1}$ & 300 & 510 & 200 & 170 & 1180 \\
\hline $\mathbf{2}$ & 220 & 485 & 275 & 80 & 1060 \\
\hline $\mathbf{3}$ & 270 & 445 & 205 & 170 & 1090 \\
\hline $\mathbf{4}$ & 310 & 407 & 340 & - & 1057 \\
\hline $\mathbf{5}$ & 245 & 405 & 200 & - & 850 \\
\hline $\mathbf{6}$ & 340 & 410 & 325 & - & 1075 \\
\hline $\mathbf{7}$ & 360 & 400 & 355 & 85 & 1200 \\
\hline $\mathbf{8}$ & 290 & 425 & 115 & 200 & 1030 \\
\hline $\mathbf{9}$ & 265 & 510 & 170 & - & 945 \\
\hline $\mathbf{1 0}$ & 340 & 490 & 235 & - & 1065 \\
\hline $\mathbf{1 1}$ & 300 & 310 & 215 & 100 & 925 \\
\hline $\mathbf{1 2}$ & 275 & 510 & 140 & - & 925 \\
\hline $\mathbf{1 3}$ & 275 & 400 & 300 & 230 & 1205 \\
\hline $\mathbf{1 4}$ & 260 & 435 & 360 & - & 1055 \\
\hline $\mathbf{1 5}$ & 315 & 435 & 310 & - & 1060 \\
\hline $\mathbf{1 6}$ & 300 & 555 & 315 & 210 & 1380 \\
\hline $\mathbf{1 7}$ & 200 & 410 & 320 & 100 & 1030 \\
\hline $\mathbf{1 8}$ & 270 & 380 & 320 & - & 970 \\
\hline $\mathbf{1 9}$ & 273 & 365 & 245 & 100 & 983 \\
\hline $\mathbf{2 0}$ & 90 & 210 & 50 & - & 350 \\
\hline $\mathbf{2 1}$ & 325 & 540 & 140 & - & 1005 \\
\hline $\mathbf{2 2}$ & 310 & 550 & 300 & - & 1160 \\
\hline $\mathbf{2 3}$ & 226 & 410 & 220 & 110 & 1225 \\
\hline $\mathbf{2 4}$ & 225 & 445 & 360 & 195 & 1145 \\
\hline $\mathbf{2 5}$ & 300 & 460 & 255 & 130 & 25.93 \\
\hline & & Total yield $(\mathbf{K g})$ & & \\
\hline
\end{tabular}


Table.3 Yield of oyster mushroom (Crop 3) February 25, 2018 - April 15, 2018

\begin{tabular}{|c|c|c|c|c|c|}
\hline Bag & 1 Harvest & 2 Harvest & 3 Harvest & 4 Harvest & Average yield per bag (gm) \\
\hline $\mathbf{1}$ & 295 & 310 & 220 & - & 825 \\
\hline $\mathbf{2}$ & 210 & 215 & 177 & 90 & 692 \\
\hline $\mathbf{3}$ & 375 & 420 & 225 & 120 & 1140 \\
\hline $\mathbf{4}$ & 200 & 425 & 320 & - & 945 \\
\hline $\mathbf{5}$ & 270 & 510 & 285 & 40 & 1105 \\
\hline $\mathbf{6}$ & 272 & 490 & 350 & - & 1112 \\
\hline $\mathbf{7}$ & 90 & 310 & 275 & - & 675 \\
\hline $\mathbf{8}$ & 325 & 510 & 255 & - & 1090 \\
\hline $\mathbf{9}$ & 265 & 435 & 270 & 200 & 1170 \\
\hline $\mathbf{1 0}$ & 330 & 445 & 140 & - & 1030 \\
\hline $\mathbf{1 1}$ & 280 & 510 & 240 & - & 1060 \\
\hline $\mathbf{1 2}$ & 345 & 395 & 320 & - & 750 \\
\hline $\mathbf{1 3}$ & 175 & 200 & 325 & 50 & 1080 \\
\hline $\mathbf{1 4}$ & 340 & 520 & 220 & - & 135 \\
\hline $\mathbf{1 5}$ & 340 & 550 & 245 & - & 935 \\
\hline $\mathbf{1 6}$ & 360 & 445 & 200 & - & 820 \\
\hline $\mathbf{1 7}$ & 290 & 510 & 135 & - & 745 \\
\hline $\mathbf{1 8}$ & 190 & 395 & 235 & - & 960 \\
\hline $\mathbf{1 9}$ & 325 & 200 & 220 & - & 1240 \\
\hline $\mathbf{2 0}$ & 260 & 520 & 180 & - & 835 \\
\hline $\mathbf{2 1}$ & 370 & 550 & 320 & - & 930 \\
\hline $\mathbf{2 2}$ & 290 & 405 & 140 & - & - \\
\hline $\mathbf{2 3}$ & 100 & 410 & 230 & - & \\
\hline $\mathbf{2 4}$ & 225 & 400 & 270 & - & \\
\hline $\mathbf{2 5}$ & 325 & 425 & 190 & - & \\
\hline & & Total yield $(\mathbf{K g})$ & & & \\
\hline & & & & & \\
\hline
\end{tabular}


Table.4 Yield of oyster mushroom (Crop 4) March 20, 2018 - May 05, 2018

\begin{tabular}{|c|c|c|c|c|c|}
\hline Bag & 1 Harvest & 2 Harvest & 3 Harvest & 4 Harvest & Average yield per bag (gm) \\
\hline $\mathbf{1}$ & 240 & 343 & 245 & - & 828 \\
\hline $\mathbf{2}$ & 200 & 333 & 295 & - & 828 \\
\hline $\mathbf{3}$ & 310 & 411 & 255 & - & 976 \\
\hline $\mathbf{4}$ & 275 & 398 & 326 & - & 999 \\
\hline $\mathbf{5}$ & 235 & 439 & 100 & - & 774 \\
\hline $\mathbf{6}$ & 320 & 475 & 322 & - & 717 \\
\hline $\mathbf{7}$ & 235 & 305 & 222 & - & 762 \\
\hline $\mathbf{8}$ & 345 & 490 & 210 & 70 & 905 \\
\hline $\mathbf{9}$ & 300 & 310 & 215 & 80 & 907 \\
\hline $\mathbf{1 0}$ & 275 & 455 & 177 & - & 680 \\
\hline $\mathbf{1 1}$ & 325 & 300 & 55 & - & 569 \\
\hline $\mathbf{1 2}$ & 197 & 372 & - & - & 968 \\
\hline $\mathbf{1 3}$ & 238 & 415 & 315 & & 355 \\
\hline $\mathbf{1 4}$ & 355 & - & - & - & 619 \\
\hline $\mathbf{1 5}$ & 360 & 259 & - & - & 760 \\
\hline $\mathbf{1 6}$ & 285 & 360 & 115 & - & 980 \\
\hline $\mathbf{1 7}$ & 290 & 435 & 255 & - & 925 \\
\hline $\mathbf{1 8}$ & 230 & 395 & 300 & - & 935 \\
\hline $\mathbf{1 9}$ & 295 & 345 & 295 & - & 730 \\
\hline $\mathbf{2 0}$ & 230 & 400 & 100 & - & 878 \\
\hline $\mathbf{2 1}$ & 270 & 468 & 140 & - & 725 \\
\hline $\mathbf{2 2}$ & 265 & 370 & 90 & - & 975 \\
\hline $\mathbf{2 3}$ & 330 & 430 & 215 & - & 7940 \\
\hline $\mathbf{2 4}$ & 280 & 410 & 350 & - & 21.14 \\
\hline $\mathbf{2 5}$ & 345 & 390 & 60 & - & \\
\hline & & Total yield (Kg) & & \\
\hline
\end{tabular}

\section{References}

Bano, Z., Rajarathnam, S., \& Nagaraja, N. (1987). Some important studies on Pleurotus mushroom technology. In International conference on science and cultivation technology of edible fungi. Jammu Tawi, India (pp. 53-64).

Çağlarırmak, N. (2007). The nutrients of exotic mushrooms (Lentinula edodes and Pleurotus species) and an estimated approach to the volatile compounds. Food chemistry, 105(3), 1188-1194.
Das, N., \& Mukherjee, M. (2007). Indoor Cultivation of $P$. ostreatus. Philo Agric, 61, 253-262.

Dundar, A., Acay, H., \& Yildiz, A. (2008). Yield performances and nutritional contents of three oyster mushroom species cultivated on wheat stalk. African Journal of Biotechnology, 7(19).

Eswaran, A., \& Ramabadran, R. (2000). Studies on some physiological, cultural and post-harvest aspects of oyster mushroom, Pleurotus eous (Berk.) sacc. 
Kalač, P. (2009). Chemical composition and nutritional value of European species of wild growing mushrooms: A review. Food chemistry, 113(1), 9-16.

Khan, A. M., Khan, S. M., \& Khan, S. M. (2001). Studies on the cultivation of Oyster mushroom Pleurotus ostreatus on different substrates. Pakistan J. Phytopath, 13(2), 140-143.

Pathmashini, L., Arulnandhy, V., \&
Wijeratnam, R. S. (2009). Cultivation of oyster mushroom (Pleurotus ostreatus) on sawdust. Ceylon Journal of Science (Biological Sciences), 37(2).

Srivastava, H. C., \& Bano, J. (2010). Studies on the cultivation of Pleurotus species on paddy straw. Food Sci, 11, 36-38.

Srivastava, H. C., \& Bano, J. (2010). Studies on the cultivation of Pleurotus species on paddy straw. Food Sci, 11, 36-38.

\section{How to cite this article:}

Chitra, K., K. Dhanalakshmi, N. Indra and Ambethgar, V. 2021. Oyster Mushroom Cultivation with Reference to Climate. Int.J.Curr.Microbiol.App.Sci. 10(10): 307-313. doi: https://doi.org/10.20546/ijcmas.2021.1010.038 